\title{
PENGARUH NPK LAO YING TERHADAP PERTUMBUHAN DAN HASIL MELON (Curcumis melo L.)
}

\author{
Sumartoyo \\ Fakultas Pertanian Universitas Kapuas Sintang \\ email:1ppmmartoyo@yahoo.co.id
}

\begin{abstract}
Abstrak: Melon (Curcumis melo L.) merupakan salah satu jenis tanaman pertanian yang penting karena banyak mengandung gizi dan diperlukan oleh manusia, oleh karenanya tanaman ini di Kalimantan Barat perlu terus dibudidayakan. Salah satu kendala dalam pembudidayaan melon di Kalimantan Barat adalah tanahnya yang didominsi oleh tanah podsolik merah kuning (PMK). Tanah PMK merupakan jenis tanah yang miskin unsur hara terutama N, P, K, dan Ca. NPK Lao Ying merupakan Janis pupuk yang kaya akan hara N, P, K, dan Ca. Pemberian NPK Lao Ying diharapkan dapat meningkatkan pertumbuhn dan hasil melon pada tanah PMK. Penelitian ini bertujuan untuk mengetahui pengaruh NPK Lao Ying terhadap pertumbuhan dan hasil melon pada tanah PMK dan untuk mendapatkan dosis NPK Lao Ying yang dapat menghasilkan pertumbuhan serta hasil melon tertinggi pada tanah PMK. Penelitian ini menggunakan metode percobaan lapangan. Penelitian ini menggunakan metode Rancangan Acak Kelompok, terdiri atas 6 perlakuan, masing-masing perlakuan diulang 4 kali. Enam perlakuan yang dimaksud: $\mathrm{n}_{0}=$ Tanpa NPK Lao Ying. $\mathrm{n}_{1}=$ NPK Lao Ying $10 \mathrm{~g}$ per $\mathrm{m}^{2} . \mathrm{n}_{2}=$ NPK Lao Ying $20 \mathrm{~g}$ per $\mathrm{m}^{2} . \mathrm{n}_{3}=$ NPK Lao Ying $30 \mathrm{~g}$ per $\mathrm{m}^{2}$. $\mathrm{n}_{4}=$ NPK Lao Ying $40 \mathrm{~g}$ per $\mathrm{m}^{2} . \mathrm{N}_{5}=$ NPK Lao Ying $50 \mathrm{~g}$ per $\mathrm{m}^{2}$. Pengamatan dilakukan terhadap peubah berat berangkasan dan berat buah per tanaman. Hasil penelitian menunjukkan bahwa NPK Lao Ying dapat meningkatkan pertumbuhan dan hasil melon, yang ditunjukkan oleh peubah berat berangkasan dan berat buah per tanaman. Pertumbuhan dan hasil tertingi akibat pemberian NPK Lao Ying dicapai pada dosis $40 \mathrm{~g}$ per $\mathrm{m}^{2}$, pada dosis tersebut menghasilkan rerata berat berangkasan per tanaman $0,506 \mathrm{~kg}$ dan rerata berat buah per tanaman $2,050 \mathrm{~kg}$.
\end{abstract}

Kata Kunci: NPK, Pertumbuhan dan Hasil, Melon.

\section{PENDAHULUAN}

Melon merupakan salah satu jenis tanaman pertanian yang penting karena banyak mengandung gizi dan diperlukan oleh manusia (Soedarya, 2013:14). Berkaitan dengan kandungan gizi pada buah melon, tanaman ini di Kalimantan Barat perlu terus dibudidayakan. Salah satu kendala dalam pembudidayaan melon di Kalimantan Barat adalah tanahnya yang didominsi oleh tanah podsolik merah kuning (PMK). Tanah PMK merupakan jenis tanah 
yang miskin unsur hara terutama $\mathrm{N}$, $\mathrm{P}, \mathrm{K}$, dan $\mathrm{Ca}$ (Hardjowigeno, 2010:235). PT Mest Indonesiy (2017:1) menjelaskan bahwa NPK Lao Ying mempunyai komponen hara $\quad \mathrm{N}: \mathrm{P}: \mathrm{K}: \mathrm{Ca}=16: 16: 16: 7$. Soedarya (2013:20-21) memaparkan bahwa tanaman melon menghedaki lingkungan tumbuh yang kaya akan $\mathrm{N}, \mathrm{P}, \mathrm{K}$, dan $\mathrm{Ca}$ dengan $\mathrm{pH}$ tanah 5,5-7,0. Berdasarkan uraian tersebut di atas pemberian NPK Lao Ying diharapkan dapat meningkatkan pertumbuhan dan hasil melon pad tanah PMK.

\section{METODOLOGI PENELITIAN}

Penelitian ini dilksanakan di desa Martiguna kecamatan Sintang kabpaten Sintang, sebagai media tanaman adalah tanah PMK. Alatalat yang digunakan: parang, cangkul, kantong plastik, gergaji triplek, kayu, tali rafia, timbangan, ember, mini sprayer, meteran, kamera. Bahan bahan yang digunakan dalam penelitian ini adalah: Benih melon: NPK Lao Ying, Tanah PMK, Air, Furadan 3G, Decis 2,5 EC, dan Antracol 70 WP.
Penelitian ini menggunakan metode percobaan lapangan, dilaksanakan dengan Rancangan Acak Kelompok, terdiri dari 6 perlakuan, masing masing perlakuan diulang empat kali ulangan, ke enam perlakuan tersebut: $\mathrm{n}_{0}=$ Tanpa NPK Lao Ying. $\mathrm{n}_{1}=$ NPK Lao Ying $10 \mathrm{~g}$ per $\mathrm{m}^{2} \cdot \mathrm{n}_{2}=$ NPK Lao Ying $20 \mathrm{~g}$ per $\mathrm{m}^{2} \cdot \mathrm{n}_{3}=$ NPK Lao Ying $30 \mathrm{~g}$ per $\mathrm{m}^{2} . \mathrm{n}_{4}=$ NPK Lao Ying $40 \mathrm{~g}$ per $\mathrm{m}^{2} . \mathrm{n}_{5}=$ NPK Lao Ying $50 \mathrm{~g}$ per $\mathrm{m}^{2}$. Pengamatan dilakukan terthadap peubah berat buah dan berat berangkasan.

Data yang diperoleh dihitung reratanya. Pemeriksan terhadap sarat syahnya analisis ragam dilakukan dengan uji Bartlet dan uji Tukey. Data dianalisis dengan sidik ragam dan dilanjutkan dengan uji BNJ pada taraf nyata 5\%. Model linier aditif yang dipostulatkan untuk menganalisis setiap peubah terikat yang diamati menurut Gaspersz (2014:118) adalah $\mathrm{Y}_{\mathrm{ij}}=\mu+\mathrm{T}_{\mathrm{i}}+\beta_{\mathrm{j}}+$ $\varepsilon_{\mathrm{ij}}$

\section{HASIL PENELITIAN}

Hasil penelitian pengaruh perlakuan terhadap peubah yang 
diamati (berat buah per tanaman dan disajikan pada Tabel 1.

berat berangkasan per tanaman)

Tabel 1. Hasil Penelitian Pengaruh Perlakuan Terhadap Peubah Yang Diamati

\begin{tabular}{ccc}
\hline \multirow{2}{*}{ Perlakuan } & \multicolumn{2}{c}{ Nilai rerata peubah yang diamati } \\
\cline { 2 - 3 } & $\begin{array}{c}\text { Berat buah per tanaman } \\
(\mathbf{k g})\end{array}$ & $\begin{array}{c}\text { Berat berangkasan per } \\
\text { tanaman }(\mathbf{k g})\end{array}$ \\
\hline $\mathrm{n}_{0}$ & $1.5313 \mathrm{a}$ & $0.3625 \mathrm{a}$ \\
$\mathrm{n}_{1}$ & $1.6563 \mathrm{ab}$ & $0.3938 \mathrm{ab}$ \\
$\mathrm{n}_{2}$ & $1.7250 \mathrm{bc}$ & $0.4169 \mathrm{ab}$ \\
$\mathrm{n}_{3}$ & $1.8125 \mathrm{c}$ & $0.4450 \mathrm{~b}$ \\
$\mathrm{n}_{4}$ & $2.0500 \mathrm{~d}$ & $0.5056 \mathrm{c}$ \\
$\mathrm{n}_{5}$ & $2.0750 \mathrm{~d}$ & $0.5313 \mathrm{c}$ \\
\hline KTG dari sidik ragam & $\mathbf{0 , 0 0 4 3}$ & $\mathbf{0 , 0 0 0 6}$ \\
\hline SE & $\mathbf{0 , 0 3 2 9}$ & $\mathbf{0 , 0 1 2 0}$ \\
\hline $\mathbf{Q}_{\mathbf{0}, 05}$ & $\mathbf{4 , 6 0 0 0}$ & $\mathbf{4 , 6 0 0 0}$ \\
$\mathbf{Q}_{\mathbf{0 , 0 1}}$ & $\mathbf{5 , 8 0 0 0}$ & $\mathbf{5 , 8 0 0 0}$ \\
\hline BNJ $_{\mathbf{0}, \mathbf{0 5}}$ & $\mathbf{0 . 1 5 1 5}$ & $\mathbf{0 . 0 5 5 4}$ \\
BNJ $_{\mathbf{0}, \mathbf{0 1}}$ & $\mathbf{0 . 1 9 1 1}$ & $\mathbf{0 . 0 6 9 8}$ \\
\hline
\end{tabular}

Sumber: Hasil analisis data, 2018

Keterangan: Nilai rerata yang diikuti huruf beda berarti berbeda nyata

Hasil penelitian menunjukkan bahwa pemberian pemberian NPK Lao Ying dosis $40 \quad \mathrm{~g}^{2} \quad \mathrm{~m}^{2} \quad\left(\mathrm{n}_{4}\right)$ memberikan pertumbuhan dan hasil yang tidak berbeda pada selang kepercayaan $95 \%$ dengan dosis $50 \mathrm{~g}$ $\mathrm{m}^{2}\left(\mathrm{n}_{5}\right)$, lebih tinggi dibanding dosis $30 \mathrm{~g} \mathrm{~m}^{2}\left(\mathrm{n}_{3}\right), 20 \mathrm{~g} \mathrm{~m}^{2}\left(\mathrm{n}_{2}\right), 10 \mathrm{~g} \mathrm{~m}^{2}$ $\left(\mathrm{n}_{1}\right)$, dan tanpa pemberian NPK Lao Ying $\left(\mathrm{n}_{0}\right)$. Berdasarkan hasil uji BNJ trsebut diputuskan perlakuan yang menberikan pertumbuhan dan hasil terttinggi adalah dosis $40 \mathrm{~g}$ per
$\mathrm{m}^{2}\left(\mathrm{~N}_{4}\right)$. Perlakuan $\mathrm{n}_{4}$ tersebut menghasilkan rerata bera buah per tanaman 2,0500 $\mathrm{kg}$ dan berat berangkasan pe tanaman $0,5056 \mathrm{~kg}$.

\section{PEMBAHASAN}

Hasil penelitian ini menunjukkan bahwa NPK Lao Ying dapat meningkatkan pertumbuhan dan hasil melon, ditunjukkan oleh peningkatan berat buah per tanaman dan berat berangkasan per tanaman. Hasil penelitian tersebut diduga 
dengan pemberian NPK Lao Ying unsur menyebabkan $\mathrm{N}, \mathrm{P} \mathrm{K}, \mathrm{S}, \mathrm{Mg}$, $\mathrm{Bo}, \mathrm{Cu}$, dan $\mathrm{Mn}$ menjadi lebih tersedia bagi tanaman, karena NPK Lao Ying mempunyai kompnen hara $\mathrm{N}, \mathrm{P} \mathrm{K}, \mathrm{S}, \mathrm{Mg}, \mathrm{Bo}, \mathrm{Cu}$, dan $\mathrm{Mn}$. Nyakpa, dkk. menjelaskan bahwa unsur $\mathrm{N}, \mathrm{P} \mathrm{K}, \mathrm{S}$, $\mathrm{Mg}, \mathrm{Bo}, \mathrm{Cu}$, dan $\mathrm{Mn}$ adalah unsur hara esensial bagi tanaman, penting sekali bagi kegiatan metabolisme tanaman. Pemanfaatan unsur N, P K, $\mathrm{S}, \mathrm{Mg}, \mathrm{Bo}, \mathrm{Cu}$, dan $\mathrm{Mn}$ yang berasal dari NPK Lao Ying oleh tanaman menyebabkan kegiatan metabolisme tanaman meningkat. Hasil-hasil metabolime tanaman selanjutnya ditrasfor ke bagian tanaman, akibtny dun mnjadi lebar dan tebal, batang menjadi besar, dan buah menjadi besar, akibat selanjutnya timbangannya bertambah.

Hasil Hasil penelitian menunjukkan bahwa prtumbuhan dan hasil tertinggi dicapai pada dosis NPK Lao Ying $40 \mathrm{~g}$ per $\mathrm{m}^{2}\left(\mathrm{n}_{4}\right)$. Hasil penelitian tersebut diduga dengan NPK Lao Ying 40 g per $\mathrm{m}^{2}$ satatus hara dalam media tumbuh telah mencapai taraf kecukupan, sehingga pemberian NPK Lao Ying di atas dosis $40 \mathrm{~g} \mathrm{~m}^{2}$ tidak lagi diikuti oleh peningkatan pertumbuhan dan hasil tanaman. Dugaan tersebut sejalan dengan penjelasan Gardner, Pearce, dan Mitchell (2001:137-138) bahwa pemberian unsur hara pada pataman yang ststatus haranya sudah berkecukupan tidak akan diikuti pertumbuhan dan hasil tanaman.

\section{KESIMPULAN DAN SARAN}

NPK NPK Lao Ying dapat meningkatkan pertumbuhan dan hasil melon, yang ditunjukkan oleh peubah berat buah dan berat berangkasan per tanaman. Pertumbuhan dan hasil tertinggi akibat pemberian NPK Lao Ying dicapai pada dosis $40 \mathrm{~g}$ per $\mathrm{m}^{2}$, pada dosis tersebut menghasilkan rerata berat buah per tanaman 2,0500 kg dan rerata berat berangkasan per tanaman $0,5056 \mathrm{~kg}$.

\section{DAFTAR PUSTAKA}

Gardner, F.P., Pearce, R.B., dan Mitchell, R.L. 2001. Diterjemahkan oleh Herawati, S. Fisiologi Tumbuhan Budidaya. Jakarta: Universitas Indonesia. 
Hardjowigeno, S. 2010. Ilmu Tanah. Jakarta: Akademik Presindo.

Nyakpa, M.Y., Lubis, A.M., Pulung, M.A., Amrah, A.G., Munawar, A., Go Ban Hong, dan Hakim, N. 1998. Kesuburan Tanah,
Lampung:Universitas

Lampung.

PT. Mest Indonesiy. 2017. Pupuk NPK Laoying: Brosur. Jakarta: PT. Mest Indonesiy.

Soedarya, A.P. 2013. Budidaya Usaha Pengolahan Agribisnis Melon. Bandung: Pustaka Grafika. 